ural History of the species. $i$. On the habits and 'Transformations of Canthion hudsonias (Forst.) - the common "Tumbledung." $j$. On the Larval Habits of the Cantharid genera Epicauta and Henous. $k$. An Instance of Replacement of Injurious Inseets by Human Agency.

* 145. The Bulletin of the Torrey Botanical Club, vol. v, contains the following.

a. Ctenucha virginica captured by Apocynum androsaemifolium (by W. H. Leggett), p. 32. b. Darlingtonia as a Fly trap (by W. B.), p. 32. $c$. Notice of Psyche, Nos. 1-4, p. 35. d. Grasshoppers [Imprisonment of locusts in flowers of Hemerocallis fulva] (by W. H. Leggett), p. 41. e. Insects destroyed by vegetables (by Austin Bacon), p. 51-52.

\title{
English Names for Butterflies.
}

(Continued from page 44.)

63. Catopsitia Eubule.-The cloudless Sulphur.

A name proposed by Gosse.

64. Colias Pelidne.-The Pink-edge.

65. Colias Philodice.-The clouded Sulphur.

66. Colias Eurytheme.-The orange Sulphur.

67. Eurema Lisa.-The little Sulphur.

68. Abceis Nicippe.-The black-bordered Yellow.

A name proposed by Gosse.

69. Ganoris rapce.-The cabbage butterfly.

Its common name.

70. Ganoris oleracea.-The gray-veined White.

A name proposed by Gosse. Harris called it the pot-herb Pontia.

71. Synchloe Protodice.-The checquered White.

72. Euchloe Genutia.-The falcate Orange-tip.

73. Laertias Philenor.-The blue Swallow-tail.

A name proposed by Gosse.

74. Pterourvis Troilus.-The green-clouded Swallow-tail.

Proposed by Gosse.

75. Euphoeades Glaucus.-The tiger Swallow-tail.

Proposed by Gosse. He called the melanic female the blaek Emperor Swallow-tail.

76. Iphiclides Ajax.-The zebra Swallow-tail.

Gosse's name.

77. Amaryssu\& Polyxenes.-The black Swallow-tail.

Proposed by Gosse.

(The names of the Skippers will not be given at present.) S.H. Seudder.

No. 10 was issued February 12, 1875. 

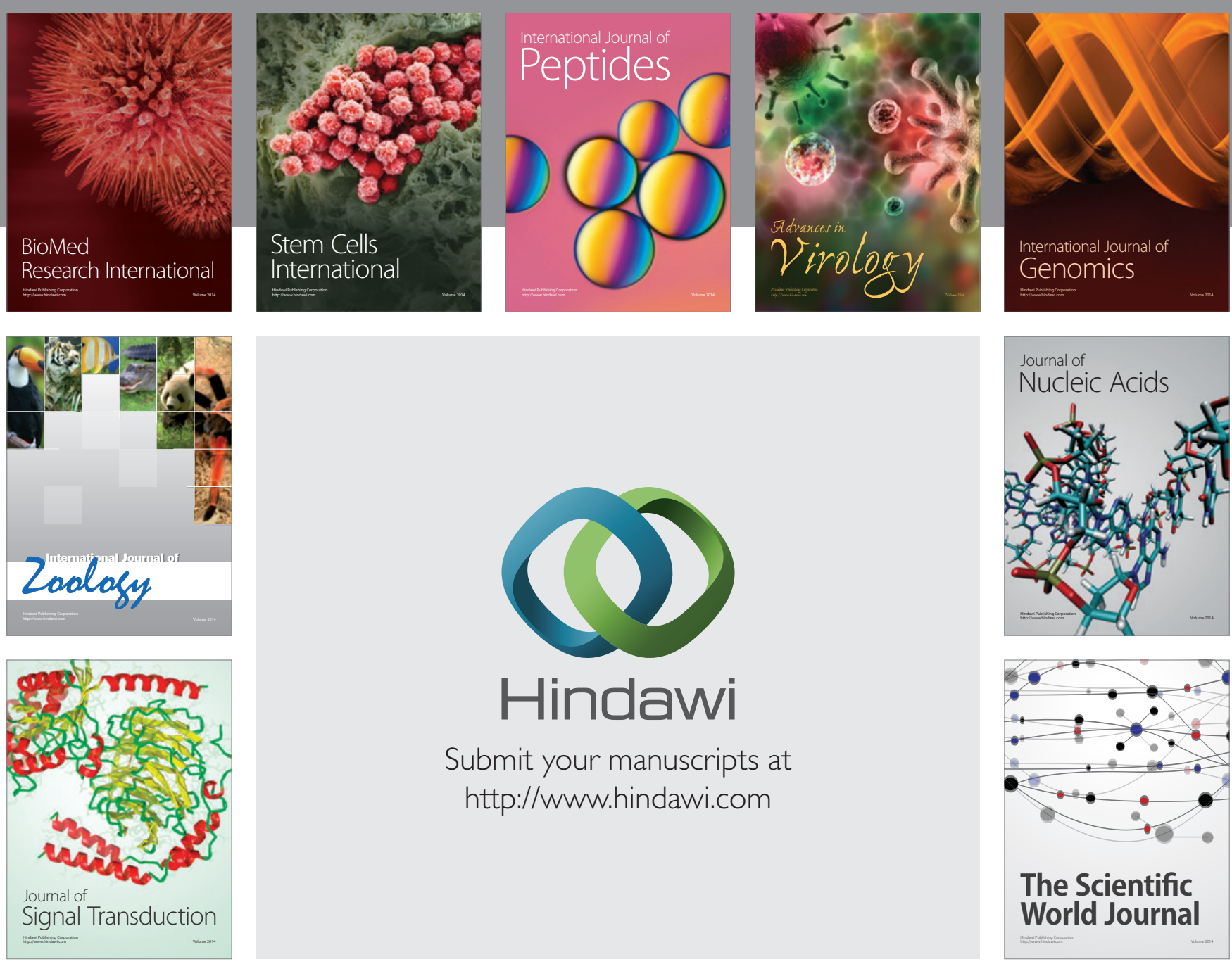

Submit your manuscripts at

http://www.hindawi.com
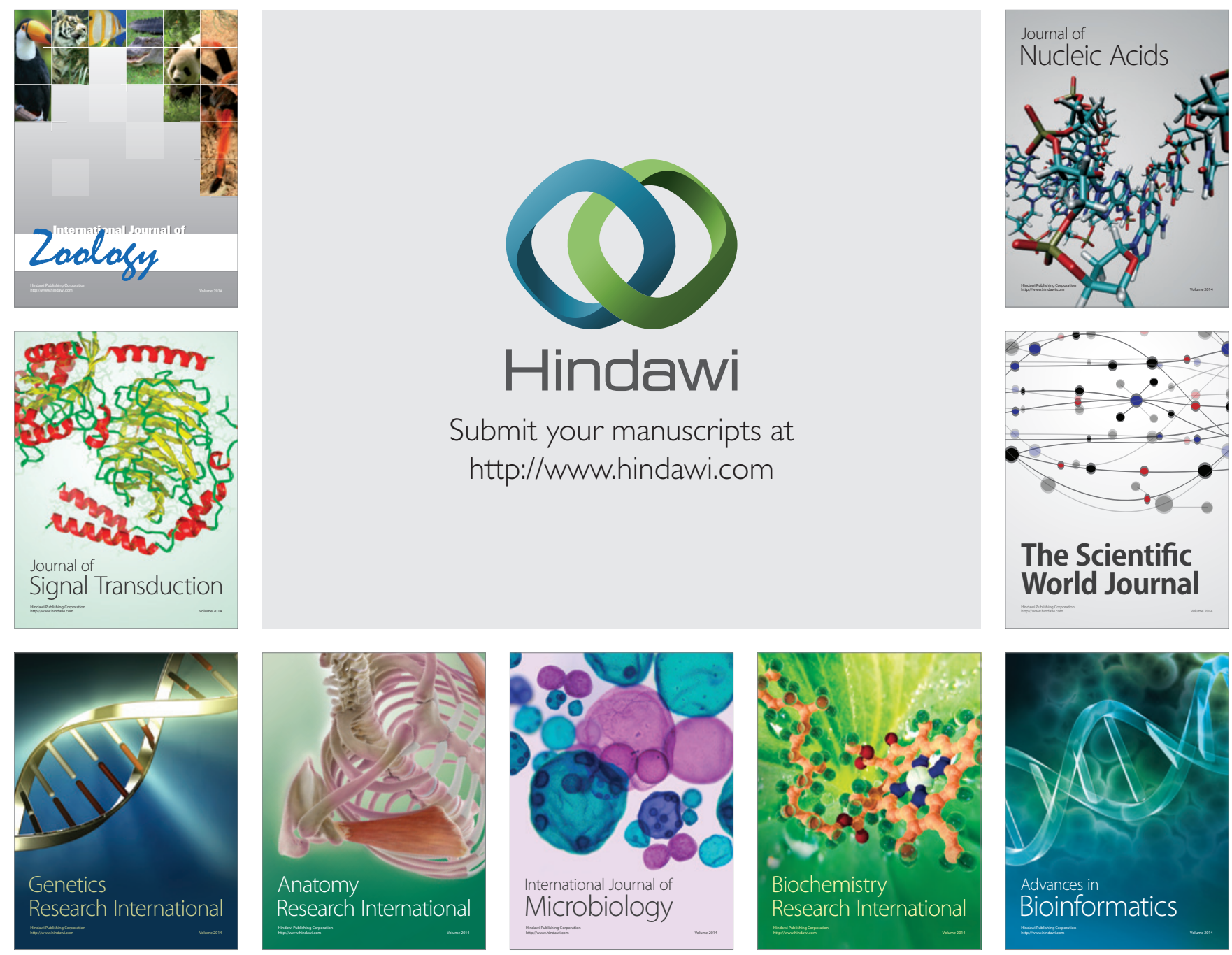

The Scientific World Journal
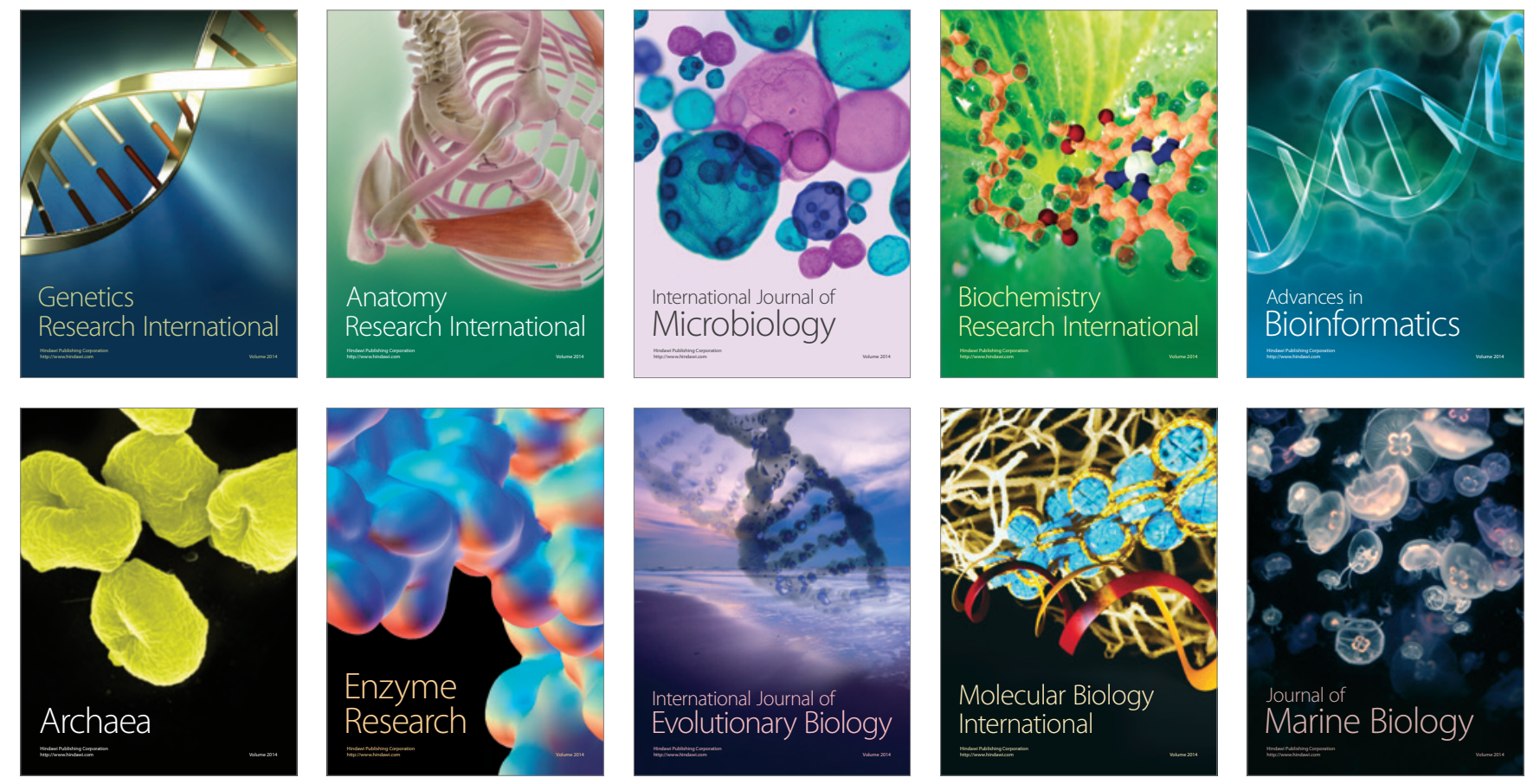